\title{
Detection of anti-hepatitis C virus antibodies by ELISA using synthetic peptides
}

\author{
Carmen Berasain, Marta García-Granero, José Ignacio Riezu-Boj, María Pilar Civeira, \\ Jesús Prieto and Francisco Borrás-Cuesta
}

Center for Biomedical Research, Department of Internal Medicine, Faculty of Medicine. University of Navarra, Departamento de Medicina Interna, Facultad de Medicina, Universidad de Navarra. Apartado 273, Pamplona, Spain

(Received 25 October 1991)

A novel ELISA assay for the detection of anti-hepatitis $\mathrm{C}$ virus antibodies in the sera of infected individuals is described. This assay is based on a mixture of three 15-amino acid synthetic peptides encompassing regions of core and NS4 proteins of hepatitis C virus. Comparison with other available ELISA assays based on recombinant polypeptides shows that, short synthetic peptides have the advantage over some larger recombinant peptides by giving higher specificity without loss of sensitivity.

Key words: Hepatitis C; ELISA assay; Anti-HCV antibodies; Synthetic peptides

Hepatitis $\mathrm{C}$ virus (HCV) is the major, if not the only cause of non-A, non-B hepatitis (1). This infection frequently progresses to chronicity (2) with a high proportion of cases evolving to cirrhosis $(3,4)$. In the Western world $\mathrm{HCV}$ is the leading cause of chronic hepatitis (2). Since the isolation and cloning of HCV by Choo et al. (5), many regions of its genome have been sequenced (6-12). This has shown that the HCV is an RNA virus with a genome of 9416 base pairs coding for a polyprotein of 3010 amino acids. This polyprotein is processed by at least two proteases (one from the virus and one from the host) which free several proteins. These proteins, by analogy with those of flaviviruses and pestiviruses have been classified into structural (core, envelope or E1, NS1/E2) and non-structural (NS2, NS3, NS4 and NS5) proteins.

Kuo et al. (13) developed an ELISA assay based on a recombinant peptide (c-100) for the detection of anti$\mathrm{HCV}$ antibodies in the sera of infected individuals. This assay (referred to as $\mathrm{O} 1$ ) was superceded by a second generation assay, also commercialized by ORTHO Diagnostics, based on recombinant fragments from structural and non structural regions of $\mathrm{HCV}$ (from now on $\mathrm{O} 2$ ). It has been reported that $\mathrm{O} 1$ detects anti-HCV antibodies late after infection (14) and also, may give false-positive results (15-19). In an attempt to solve these problems we developed an ELISA assay based on synthetic peptides (20). In this study the results of our assay are compared with those of $\mathrm{O} 1, \mathrm{O} 2$ and with a prototype developed by Welcome laboratories (from now on $W$ ) also based on recombinant antigens from structural and non structural regions of $\mathrm{HCV}$.

\section{Materials and Methods}

\section{Sera from patients and controls}

Blood donors sera (panel 1): The sera from 221 blood donors were used as negative controls.

Chronic non-A, non-B hepatitis sera (panel 2): The sera from 150 patients fullfilling the following criteria: liver biopsy showing chronic persistent or chronic active hepatitis with or without cirrhosis, presence of raised serum alanine aminotransferase for more than 6

Correspondence to: Francisco Borrás-Cuesta, Departamento de Medicina Interna, Facultad de Medicina, Universidad de Navarra, Apartado 273, Pamplona, Spain. 
months, negativity for $\mathrm{HBsAg}$, alcohol consumption less than $50 \mathrm{~g} /$ day, antinuclear antibodies negative or a titre lower than $1 / 100$, absence of potential hepatotoxic drugs, normal levels of ceruplasmin and $\alpha$-1-antitrypsin.

Chronic hepatitis B sera (panel 3): The sera from 98 HBsAg positive patients with biopsy proven chronic hepatitis.

Other sera (panel 4): 115 serum samples consecutively received in the laboratory from hemodyalisis patients and patients with hypertransaminasemia.

\section{Peptide synthesis}

Peptides were synthesized by the solid-phase method of Merrifield (21) using the Fmoc alternative (22) with a manual multiple solid-phase synthesizer which can synthesize up to 96 independent peptides (23). The ninhydrin test of Kaiser (24) was used to monitor the coupling and deprotection steps. At the end of the synthesis, peptides were cleaved and deprotected followed by two washings with diethyl ether. They were used for the ELISA assays without further purification.

\section{ELISA assay}

The ELISA plates (Nunc-Immunoplate MaxiSorp, Denmark) were coated at $4^{\circ} \mathrm{C}$ overnight with a mixture of peptides dissolved in $0.1 \mathrm{M}$ sodium carbonate. This was done by adding $200 \mu \mathrm{l} /$ well of this solution containng $5 \mu \mathrm{g} / \mathrm{ml}$ of each peptide. The plates were washed :hree times with phosfate-saline buffer ( $\mathrm{pH} 7.2)$ containng $0.1 \%$ of Tween- 20 (PBST). The plates were then insubated at $37^{\circ} \mathrm{C}$ for $45 \mathrm{~min}$ with $210 \mu \mathrm{l} /$ well of a 1/21-serum dilution in PBST containing $1 \%$ powdered nilk (PBSTM). Two positive and three negative sera vere used as controls. After washing three times with 'BST, $200 \mu \mathrm{l} /$ well of $1 / 2000$ biotinilated goat antiIuman antibody (Amersham, UK) and 1/500 strepavidine peroxidase (Amersham, UK) in PBST was Idded and incubated at $37^{\circ} \mathrm{C}$ for $30 \mathrm{~min}$. After 3 washngs with PBST, the plates were developed in the dark t room temperature for $15 \mathrm{~min}$ with $100 \mu \mathrm{l} /$ well of a solttion of $0.4 \mathrm{mg} / \mathrm{ml}$ of $o$-phenylendiamine in $0.05 \mathrm{M}$ itrate (pH 5) buffer containing $0.014 \%$ hydrogen peroxje. The reaction was stopped by adding $75 \mu \mathrm{l} /$ well of 4 $\mathrm{J}$ sulphuric acid. The plates were read at $492 \mathrm{~nm}$ using Titertek Multiscan MK II. The cut off was calculated $y$ adding 0.4 optical density units to the average eading of the three negative control sera.

\section{'ommercial ORTHO HCV ELISA assays}

These assays (Ortho first and second generation isays, $\mathrm{O} 1$ and $\mathrm{O} 2$ ) were carried out according to the assays, $\mathrm{O} 1$ and $\mathrm{O} 2$ ) were carried out according to the manufacturers (Ortho Diagnostics Systems, Raritan, New Jersey) instructions.

\section{Wellcome HCV assay}

This assay is an ELISA assay based on a recombinant viral antigen polypeptide named $\mathrm{BHCl0}$ encompassing regions from both the core and NS5 regions of the virus (Wellcome Diagnostics, Beckenham, Kent). It was carried out as described elsewhere (25).

\section{RIBA assay}

The second generation RIBA assay from CHIRON was carried out according to the manufacturers instructions.

\section{Serological markers of hepatitis $B$ virus infection}

Serological markers of hepatitis B viral infection were investigated by RIA or ELISA with commercial reagents (Ausria II, Ausab, Corab, IMx HBsAg, Ausab EIA, IMx core; Abbott Laboratories, Chicago, Illinois).

\section{PCR analysis}

This analysis was carried out after reverse transcription of non-A, non-B viral sequences to cDNA. The amplification was done as described (25) using primers from the $5^{\prime}$ non-coding region of the virus (26).

\section{Results}

In order to select linear epitopes useful for ELISA from the proteins coded by the HCV genome, over 300 peptides of 15 amino acids in length were synthesized. These peptides encompass most regions of viral proteins. The core and envelope proteins were especially explored with three sets of peptides to cover the whole sequence and each set differing from the other by a frame shift of 5 amino acids.

To detect the peptides that were recognized by the majority of non-A, non-B sera and to discard those that were recognized by the immunoglobulins other than anti-HCV immunoglobulins, all peptides were tested by ELISA against the sera of 31 blood donors and 65 patients with non-A, non-B chronic hepatitis.

It was found that three peptides (two from core and one from NS4 proteins) taken together would allow the detection of anti-HCV antibodies in $95 \%$ of the non-A, non-B sera without cross-reacting with any of the healthy control sera. These results encouraged us to use a mixture of these three peptides to develop an ELISA 
assay for the detection of anti-HCV antibodies in the sera. From now on this assay will be referred to as $P$. To compare the specificity and sensitivity of $\mathrm{O} 1, \mathrm{O} 2, \mathrm{~W}$ and $P$ assays, the sera were classified as follows:

$H C V$ positive serum: The serum is positive if the result is positive for at least one pair of the following assays: O2, W, P, RIBA, PCR.

$H C V$ negative serum: The serum is negative if the result is negative for all assays or positive for only one of them.

These definitions were used to classify the sera from four different panels.

All the sera from panel 1 ( 221 blood donors) were classified as negative because they were negative to $\mathrm{O} 1$, $\mathrm{O} 2, \mathrm{~W}$ and $\mathrm{P}$ assays.

The results obtained with panel 2 (non-A, non-B chronic hepatitis patients) are shown on Table 1a. The sera were classified as 142 positive and 8 negative. The 142 positive sera were detected by $\mathrm{O} 2, \mathrm{~W}$ and $\mathrm{P}$ but only 108 were detected by $\mathrm{OI}$. Nineteen sera, from the 34 not detected by $\mathrm{O} 1$ but detected by $\mathrm{O} 2, \mathrm{~W}$ and $\mathrm{P}$, were tested by PCR. Eighteen out of the $19(94.7 \%)$ sera tested were PCR positive.

The results obtained with panel 3 (hepatitis B patients) are shown on Table $1 \mathrm{~b}$ and Fig. 1 . The sera were classified as 22 positive and 76 negative. Assays $\mathrm{O} 1, \mathrm{O} 2$, $\mathrm{W}$ and $\mathrm{P}$ gave 13,13, 0 and 1 false-positive results, respectively because they attributed a positive result to a serum classified as negative. Similarly, O1, O2, W and $P$ gave $9,1,5$ and 3 false-negative results.

The results obtained with panel 4 (other sera) are shown on Table 1c. The sera were classified as 56

\section{TABLE 1}

Positive results assigned by $\mathrm{O} 1, \mathrm{O} 2, \mathrm{~W}$ and $\mathrm{P}$ ELISA assays in three panels of sera. Concordance of these assignations with the final classification $^{\mathrm{a}}$ of these sera

\begin{tabular}{lrrrr}
\hline Classification & \multicolumn{5}{c}{ Number of positive sera to } \\
\cline { 2 - 5 } & $\mathrm{O} 1$ & $\mathrm{O} 2$ & $\mathrm{~W}$ & $\mathrm{P}$ \\
\hline (a) Panel 2: non- $A$, non- $B$ hepatitis & sera & 142 & 142 & 142 \\
142 HCV positive sera & 108 & 142 & 0 & 0 \\
$8 \mathrm{HCV}$ negative sera & 0 & 0 & & \\
(b) Panel 3: Hepatitis $B$ sera & & & & \\
22 HCV positive sera & 13 & 21 & 17 & 19 \\
$76 \mathrm{HCV}$ negative sera & $13^{\mathrm{b}}$ & $13^{\mathrm{b}}$ & 0 & 1 \\
(c) Panel 4: other sera & & & & \\
$56 \mathrm{HCV}$ positive sera & $\mathrm{NT}$ & 54 & 52 & 53 \\
$59 \mathrm{HCV}$ negative sera & $\mathrm{NT}$ & 2 & 0 & $\mathrm{I}$
\end{tabular}

${ }^{a}$ The definitions for positive and negative anti-HCV sera are given in Results section.

${ }^{b}$ Seven of these 13 sera are the same in $\mathrm{O} 1$ and $\mathrm{O} 2$ assays (NT) not tested.

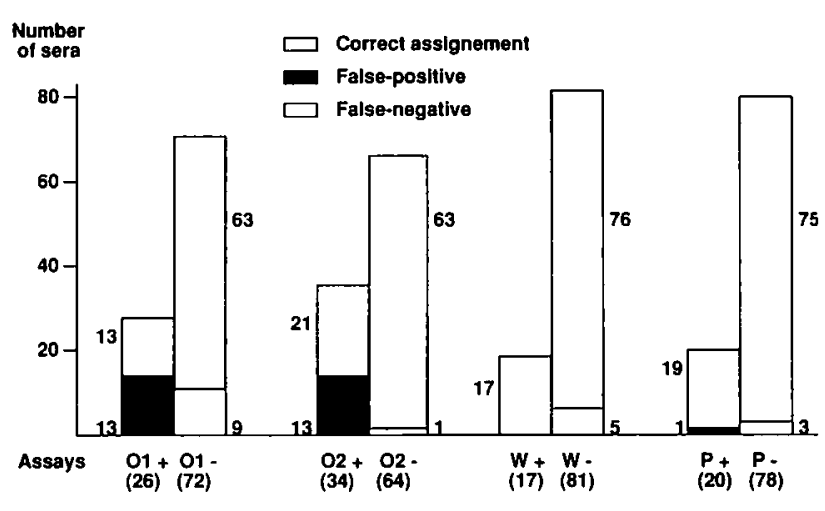

Fig. 1. Comparison of the efficacy of 4 ELISA assays: O1, O2, W and $P$ in the detection of anti-HCV antibodies in the sera of 98 patients with chronic hepatitis $B$ (panel 3 ). The number of positive and negative results obtained with each assay are indicated in brackets under each bar.

positive and 59 negative. Assays $\mathrm{O} 2, \mathrm{~W}$ and $\mathrm{P}$ gave 2,0 and 1 false-positive and 2, 4 and 3 false-negative, respectively.

Taking into account the results obtained with the four panels of sera (584 sera in total) we calculated the percentages of sensitivity and specificity of $\mathrm{O} 2, \mathrm{~W}$ and P. These percentages are shown in Table 2.

\section{Discussion}

The results for non-A, non-B sera (Table la) show that assays $\mathrm{O} 2, \mathrm{~W}$ and $\mathrm{P}$ have the same sensitivity. This sensitivity is much higher than O1. Clearly, the extra recombinant peptides added to $\mathrm{O} 1$ to give $\mathrm{O} 2$ have increased assay sensitivity by providing additional 'recognizable' epitopes.

With respect to assay specificity the results of Table 1 and Fig. 1 indicate that both $W$ and $P$ are more specific than $\mathrm{O} 1$ and $\mathrm{O} 2$. Moreover, the similar lack of specificity of $\mathrm{O} 1$ and $\mathrm{O} 2$ found in panel 3 (false-positives shown in Fig. 1 and Table $1 \mathrm{~b}$ ) might be due to a cross-

TABLE 2

Comparison of the sensitivity and specificity of $\mathrm{O} 2, \mathrm{~W}$ and P ELISA assays

\begin{tabular}{llcl}
\hline & \multicolumn{3}{l}{ Assays } \\
\cline { 2 - 4 } & O2 & W & P \\
\hline Sensitivity & $98.6 \%$ & $95.9 \%$ & $97.3 \%$ \\
Specificity & $95.9 \%$ & $100 \%$ & $99.4 \%$ \\
\hline
\end{tabular}


reaction of antigen c-100 (which is used in $\mathrm{Ol}$ and $\mathrm{O} 2$ ) with antibodies other than anti-HCV antibodies. This suggests that a similar epitope might be present in the proteins of hepatitis B virus and the c-100 antigen. To explore this hypothesis a sequence homology between c100 and the different proteins from HBV was looked for. The peptide LQTLPANPPPAS, amino acids 75-87 of pre-S1 protein of ayw HBV serotype (one of the two most common serotypes in Spain) were found to be very similar to the peptide LSTLPGNPAIAS, amino acids 1778-1789 from the NS4 region of HCV and contained by c- 100 antigen. Indeed, eight out of 12 amino acids are identical in both peptides. These two peptides were synthesized and used as antigens in an ELISA assay against the false-positive of $\mathrm{O} 1$ and $\mathrm{O} 2$ of panel 3. Since it was found that $42 \%$ of these sera recognized both peptides, we believe that these antibodies might be responsable for some of the false positive results observed when using the $\mathrm{O} 1$ and $\mathrm{O} 2$ assays.

An ELISA assay based on synthetic peptides has been recently published by Hosein et al. (27). We have not had access to this assay and for this reason were unable to compare it with our own. Moreover, since their results are only compared with $\mathrm{O} 1$, which has low sensitivity and poor specificity, no conclusions could be drawn concerning its relative value with respect to $\mathrm{O} 2, \mathrm{~W}$ and $P$ assays.

Because of their size, recombinant protein fragments have the advantage of containing a potentially high number of 'recognizable' epitopes. For similar reasons they also have the risk of encompassing epitopes that might cross-react with other antibodies not elicited by the HCV and give false-positive results - antibodies induced by a common antigen like those from influenza virus for example - . Moreover, recombinant peptides are usually expressed as fusion peptides with a protein that is easily expressed. This enhances the possibility of cross-reactivity even more. Thus, it has been reported (16) that superoxidismutase (SOD, the fusion protein with which the c-100 fragment of the $\mathrm{Ol}$ assay is expressed) might be responsible for the false-positive results of $\mathrm{O} 1$ in the case of autoimmune chronic active hepatitis.

Unlike recombinant polypeptides, short synthetic peptides (of around 15 amino acids) cannot detect antibodies induced against most conformational epitopes of the antigen. However, since they restrict antibody recognition to smaller molecules, the risk of possible cross-reaction with undesirable antibodies is diminished. Indeed, as shown in Table 2, anti-HCV antibodies can be detected by ELISA with short synthetic peptides with similar sensitivity and better specificity than with some large recombinant antigens.

\section{Acknowledgements}

Supported by grants from the Fundación Ramón Areces, Spain and from CICYT, Spain Grant No. SAL 90-0625.

\section{References}

1 Choo QL, Weiner AJ, Overby LR, Kuo G, Houghton M. Hepatitis $C$ virus: the major causative agent of viral non-A, non-B hepatitis. Br Med Bull 1990; 46: 423-41.

2 Rakela J, Redeker AG. Chronic liver disease after acute non-A, non-B viral hepatitis. Gastroenterology 1979; 77: 1200-2.

3 Mattsson L, Weiland $O$, Glaumann $H$. Chronic non-A, non-B hepatitis developed after transfusion, illicit self injections or sporadically. Outcome during long-term follow up. A comparison. Liver 1989; 9: 120-7.

4 Hopf U, Moller B, Kuther D, et al. Long term follow up of postransfusion and sporadic chronic hepatitis non- $A$, non-B and frequency of circulating antibodies to hepatitis $C$ virus (HCV). J Hepatol 1990; 10: 69-76.

5 Choo QL, Kuo G, Weinger AJ, Overby LR, Bradley DW, Houghton M. Isolation of a cDNA clone derived from a bloodborned non-A, non-B viral hepatitis genome. Science 1989; 244: 359-62.

6 Kubo Y, Takeuchi K, Boonmar S, et al. A cDNA fragment of hepatitis $C$ virus isolated from an implicated donor of posttransfusion non-A, non-B hepatitis in Japan. Nucleic Acid Res 1989; 17: 10367-72.

7 Kato N, Hijikata M, Ootsuyama Y, et al. Molecular cloning of the human hepatitis $C$ virus genome from Japanese patients with non-A, non-B hepatitis. Proc Natl Acad Sci USA 1990; 87: 9524-8.

8 Takeuchi K, Kubo Y, Boonmar S, et al. The putative nucleocapsid and envelope protein genes of hepatitis $\mathrm{C}$ virus determined by comparison of the nucleotide sequences of two isolates derived from an experimentally infected chimpanzee and healthy human carriers. J Gen Virol 1990; 71: 3027-33.

9 Okamoto H, Okada S, Sugiyama Y, et al. The 5'-Terminal Sequence of the Hepatitis C Virus Genome. Japan J Exp Med 1990; 60: $167-77$.

10 Takamizawa A, Mori C, Fuke I, et al. Structure and Organization of the Hepatitis C Virus Genome Isolated from Human Carriers. J Virol 1991; 65: 1105-13.

11 Choo QL, Richman KH, Han JH, et al. Genetic organization and diversity of the hepatitis $C$ virus. Proc Natl Acad Sci USA $1991 ; 88: 2451-5$.

12 Weiner AJ, Brauer MJ, Rosenbatt J, et al. Variable and hypervariable domains are found in the regions of $\mathrm{HCV}$ corresponding to the flavivirus envelope and NSI proteins and the pestivirus envelope glycoproteins. Virology $1991 ; 180$ : 842-8.

13 Kuo G, Choo QL, Alter $\mathrm{HJ}$, et al. An assay for circulating antibodies to a major etiologic virus of human non-A, non-B hepatitis. Science 1989; 244: 362-4.

14 Alter HJ, Purcell RH, Shih JW, et al. Detection of antibodies to hepatitis $C$ virus in prospectively followed transfusion recipients with acute and chronic non-A, non-B hepatitis. New Engl J Med 1989; 321: 1494-1500.

15 Widell A, Sundstrom G, Hansson BG, et al. Antibodies to hepatitis-C-virus-related proteins in sera from alanineaminotransferase-screened blood donors and prospectively studied recipients. Vox Sang 1991; 60: 28-33.

16 Ikeda $Y$, Toda G, Hashimoto N, Kurokawa K. Antibody to superoxide dismutase, autoimmune hepatitis and antibody tests for hepatitis C. Lancet 1990; 335: 1345-6. 
17 Theilman L, Blazek M, Goeser T, Gmelin K, Kommerell B, Fiehn W. False-positive anti-HCV tests in rheumatoid arthritis. Lancet 1990; 335: 1346.

18 Boudart D, Lucas JC, Muller JY, LeCauer D, Planchon B, Harrousseau JL. False-positive hepatitis $\mathrm{C}$ virus antibody tests in para proteinaemia. Lancet 1990; 336: 63.

19 Mcfarlane IG, Smith HM, Johnson PJ, Bray GP, Vergani D, Williams $\mathbf{R}$. Hepatitis $\mathrm{C}$ virus antibodies in chronic active hepatitis: pathogenetic factor or false-positive result?. Lancet 1990; 335: 754-7.

20 Berasain C, Garcia-Granero M, Riezu-Boj JI, Prieto J, BorrásCuesta F. Synthetic peptides for the detection of anti-hepatitis C virus antibodies in the sera of infected individuals. British patent application 9105871.9, March 1991.

21 Merrifield RB. Solid phase peptide synthesis. I. The synthesis of a tetrapeptide. J Am Chem Soc 1963; 85: 2149-54.

22 Atherton E, Logan JC, Sheppard CR. Peptide synthesis. Part 2. Procedures for solid phase synthesis using $N$-fluorenil metoxicarbonil amino acids on polyamide supports. Synthesis of substance
$P$ and of acyl carrier protein 65-74 decapeptide. J Chem Soc Perkin Trans 1981; 1: 538-46.

23 Borrás-Cuesta F. Aparato para la síntesis múltiple de péptidos por el método en fase sólida. Spanish patent application P9000764, March 1990.

24 Kaiser E, Colescott RL, Bossinger CD, Cook PI. Color test for detection of free terminal amino groups in the solid phase synthesis of peptides. Anal Biochem 1970; 34: 595-8.

25 Riezu-Boj JI, Parker D, Civeira MP, Phippard D, Corbishley TP, Camps J, Castilla A and Prieto J. Detection of hepatitis C virus antibodies with new recombinant antigens: assessment in chronic liver diseases. J. Hepatol. in press.

26 Garson JA, Ring C, Tuke P, Tedder Rs. Enhanced detection by PCR of hepatitis C virus RNA. Lancet 1990; 336: 878-9.

27 Hosein B, Fang CT, Popvsky MA, Ye J, Zhang M, Wang CY. Improved serodiagnosis of hepatitis $C$ virus infection with synthetic peptide antigen from capside protein. Proc Natl Acad Sci USA 1991; 88: 3647-51. 